medRxiv preprint doi: https://doi.org/10.1101/2021.03.11.21253192; this version posted March 12, 2021. The copyright holder for this preprint (which was not certified by peer review) is the author/funder, who has granted medRxiv a license to display the preprint in It is made available under a CC-BY-ND 4.0 International license.

\title{
Predicting the onset of freezing of gait in de novo Parkinson's disease
}

Fengting Wang ${ }^{1,3 \#}$, Yixin $\mathrm{Pan}^{1,2 \#}$, Miao Zhang ${ }^{4}, \mathrm{Kejia} \mathrm{Hu}^{1,2,5 \bowtie}$

${ }^{1}$ Department of Neurosurgery, Ruijin Hospital, Shanghai Jiao Tong University School of Medicine, Shanghai, 200025, China,

${ }^{2}$ Center for Functional Neurosurgery, Ruijin Hospital, Shanghai Jiao Tong University School of Medicine, Shanghai, 200025, China,

${ }^{3}$ Shanghai Jiao Tong University School of Medicine, Shanghai, 200025, China,

${ }^{4}$ Department of Nuclear Medicine, Ruijin Hospital, Shanghai Jiao Tong University School of Medicine, Shanghai, 200025, China,

${ }^{5}$ Laboratory of Digital Medicine, Wuxi People's Hospital, Nanjing Medical University, Wuxi, 214023, China.

${ }^{\#}$ F. Wang and Y. Pan contributed equally to this work. 
medRxiv preprint doi: https://doi.org/10.1101/2021.03.11.21253192; this version posted March 12, 2021. The copyright holder for this

\section{Abstract}

Freezing of gait (FoG) is a debilitating symptom of Parkinson's disease (PD) related to higher risks of falls and poor quality of life. In this study, we predicted the onset of FoG in PD patients using a battery of risk factors from patients enrolled in the Parkinson's Progression Markers Initiative (PPMI) cohort. The endpoint was the presence of FoG, which was assessed every year during the five-year follow-up visit. Overall, 212 PD patients were included in analysis. Seventy patients (33.0\%) developed FoG during the visit (pre-FoG group). Age, bradykinesia, TD/PIGD classification, fatigue, cognitive impairment, impaired autonomic functions and sleep disorder were found to be significantly different in patients from pre-FoG and non-FoG groups at baseline. The logistic regression model showed that motor factors such as TD/PIGD classification $(\mathrm{OR}=2.67,95 \% \mathrm{CI}=1.41-5.09)$, MDS-UPDRS part III score $(\mathrm{OR}=1.05,95 \% \mathrm{CI}=1.01-1.09)$ were associated with FoG occurrence. Several indicators representing non-motor symptoms such as SDMT total score (OR = $0.95,95 \% \mathrm{CI}=0.91-0.98), \mathrm{HVLT}$ immediate/Total recall $(\mathrm{OR}=0.91,95 \% \mathrm{CI}=$ 0.86-0.97), MOCA (OR = 0.87, 95\% CI =0.76-0.99), Epworth Sleepiness Scale (OR $=1.13,95 \% \mathrm{CI}=1.03-1.24)$, fatigue $(\mathrm{OR}=1.98,95 \% \mathrm{CI}=1.32-3.06)$, SCOPA-AUT gastrointestinal score $(\mathrm{OR}=1.27,95 \% \mathrm{CI}=1.09-1.49)$ and SCOPA-AUT urinary score $(\mathrm{OR}=1.18,95 \% \mathrm{CI}=1.06-1.32)$ were found to have the predictive value. PD patients that developed FoG showed a significant reduction of DAT uptake in the striatum. However, no difference at baseline was observed in genetic characteristics and CSF biomarkers between the two patient sets. Our model indicated that TD/PIGD classification, MDS-UPDRS total score, and Symbol Digit Modalities score were independent risk factors for the onset of FoG in PD patients. In conclusion, the combination of motor and non-motor features including the akinetic subtype and poor cognitive functions should be considered in identifying PD patients with high risks of FoG onset. 


\section{Introduction}

Freezing of gait (FoG), defined as a sudden inability to initiate or continue gait, is one of the most disabling symptoms in $\mathrm{PD}^{1}$. As a common symptom in advanced $\mathrm{PD}$, it is associated with an increased risk of severe symptom, apathy and poor quality of life ${ }^{2,3}$. The episodic nature of FoG duration and a multifaceted pathophysiology make it hard to find a unified pathogenetic mechanism ${ }^{4}$. Yet studies indicate that the dopaminergic insult in the sensorimotor striatum, as well as dysfunctional cortical and cerebellar projections may contribute to its manifestation ${ }^{1}$. While specific therapy is still underway, early prediction of FoG could help identify FoG patients and take preventive measures beforehand ${ }^{5}$.

Previous studies have concentrated on complex determinants and pathophysiology of FoG $^{6}$. Only a few studies have made efforts to predict FoG onset, especially in newly diagnosed PD patients ${ }^{7-16}$. Wearable sensors have been a heated topic used to detect and predict FoG, but these are applied to a limited number of patients and have a significant variability in outcomes measured ${ }^{17}$. Clinical variables, biomarkers and imaging examinations are feasible and convenient in evaluating FoG development. Several factors should be taken into consideration when identifying potential FoG patients. Motor factors such as higher scores of rigidity, postural instability, bradykinesia were predictive of FoG, as was shown in early studies ${ }^{7}$. The motor symptoms formed the akinetic-rigid PD subtype, which itself was identified to be a risk factor ${ }^{8}$. Non-motor factors included specific cognitive deficits, mood and sleep disorders, which were also found to be associated with FoG occurrence ${ }^{8-12}$. Imaging parameters included striatal dopaminergic denervation, which can be examined through the dopamine transporter (DAT) scans and single photon emission computed tomography (SPECT) imaging ${ }^{6}$. PD patients that had a lower DAT activity in caudate nucleus and putamen were at a higher risk to develop FoG ${ }^{10}$. Besides, white matter hyperintensities $^{13}$, biomarkers in cerebral spinal fluid ${ }^{9}$ and gene mutations ${ }^{14}$ were suggested to be predictive of or involved in the mechanisms of FoG onset. While previous studies have helped identify several FoG risk factors, there were supporting 
and refuting evidence for the results. Most studies had the median follow up duration of less than five years, while several analyses have included PD patients with the presence of FoG symptom at baseline ${ }^{7,15}$. These were not consistent with our hope to identify PD patients at risk before symptom onset.

Instead of focusing on one certain aspect of clinical or imaging assessments, our study analyzed a comprehensive battery of indicators to predict FoG onset. Motor and non-motor factors, genetic characteristics, CSF biomarkers as well as the neuroimaging parameters were evaluated using longitudinal data of five-year visit from the PPMI cohort. Our goal was to determine the early symptoms and characteristics exhibited in PD patients before FoG occurrence and help elucidate the relations of these factors with FoG occurrence and development.

\section{Material and methods}

\section{Study design and participants}

Data used in the preparation of this article were obtained from the PPMI database (www.ppmi-info.org/data). PPMI is a comprehensive observational, international, multi-center study designed to identify PD progression biomarkers. Its cohort comprises more than 400 recently diagnosed PD followed longitudinally for clinical, imaging and biospecimen biomarker assessment using standardized data acquisition protocols at 21 clinical sites. PD subjects were required to be over 30 years old, untreated with PD medications, within two years of diagnosis, Hoehn and Yahr $<3$, and to have either at least two of resting tremor, bradykinesia, or rigidity (must have either resting tremor or bradykinesia) or a single asymmetric resting tremor or asymmetric bradykinesia at enrollment. Every study included in PPMI was approved by the institutional review board at each site and had obtained written informed consent provided by the participants.

Data from patients with PD with five-year follow-up were included in this analysis. The database was accessed on December 10,2020. The last time for the update of the baseline data was April 20, 2020. Two patient groups formed in our study were based 
medRxiv preprint doi: https://doi.org/10.1101/2021.03.11.21253192; this version posted March 12, 2021. The copyright holder for this preprint (which was not certified by peer review) is the author/funder, who has granted medRxiv a license to display the preprint in It is made available under a CC-BY-ND 4.0 International license.

on the presence or absence of FoG within five years of visit. FoG was assessed using the reported value from Movement Disorders Society- Unified Parkinson's Disease Rating Scale (MDS-UPDRS) Part II item 'Freezing' and Part III item 'Freezing of gait'. The value scored of 1 or higher was converted to 1 representing the presence of FoG, while 0 represented no FoG onset. Overall, 212 subjects were included in the analysis with 142 non-FoG subjects and 70 subjects exhibiting FoG onset in five-year visit $^{18}$.

\subsection{Baseline assessments}

A comprehensive collection of motor and non-motor features, as well as imaging assessments and genotyping, were recorded at baseline and each visit year. Motor symptoms included in the study were resting tremor, rigidity, bradykinesia, postural instability at diagnosis; Tremor Dominate (TD) /Postural Instability and Gait Difficulty (PIGD) classification; tremor score; Movement Disorders Society-Unified Parkinson Disease Rating Scale (MDS-UPDRS) part II and III. Modified Schwab \& England ADL score was recorded to evaluate activities of daily living.

Non-motor symptoms were evaluated by the following items: MDS-UPDRS part I; Montreal Cognitive Assessment (MOCA) to assess global cognition; MCI test scores to evaluate test-based mild cognitive impairment (MCI); Hopkins Verbal Learning Test (HVLT) to assess memory; the 40-item University of Pennsylvania Smell Identification Test (UPSIT) to assess olfactory function; Benton Judgement of Line Orientation Test to assess visuospatial function; Epworth Sleepiness Scale and REM sleep behavior disorder questionnaire to assess sleep behavior; Geriatric Depression Scale, State-Trait Anxiety Inventory (STAI), and Questionnaire for Impulsive-Compulsive Disorders (QUIP) to assess neuron-behavior; Symbol Digit Modalities Test (SDMT) to assess processing speed-attention; Letter Number Sequencing and semantic (animal) fluency test to assess executive abilities-working memory; Scales for Outcomes in Parkinson's Disease-Autonomic (SCOPA-AUT) to assess autonomic function. 
Cerebrospinal fluid (CSF) biomarkers were recorded including CSF amyloid- $\beta 1-42$ (Abeta), total (t)-tau (Tau), and phosphorylated tau (pTau) and alpha-synuclein (aSyn). Genetic patterns of the microtubule-associated protein tau (MAPT), the apolipoprotein $\varepsilon 4$ (APOE4) allele, mutations in $\alpha$-synuclein (SNCA) including SNCA_rs3910105 and SNCA_rs356181 were tested in the patient cohorts. Subjects with missing value in genetic patterns, imaging assessments and demographic information were screened out of the study.

\subsection{SPECT-DAT and Structural MRI imaging}

Indexes of reconstructed and attenuation-corrected 123I-FP-CIT SPECT imaging data was downloaded from the PPMI website. All participants underwent a DAT imaging procedure to measure the amount of dopamine in the brain using SPECT with the DAT tracer 123I-ioflupane at baseline. The striatal-binding ratios were calculated for left and right striatum separately using the occipital lobe as reference, thus obtaining ipsilateral, contralateral, and mean measurements. The asymmetry index was calculated as below:

$$
\text { Asymmetry Index }=\left|\frac{\text { left }- \text { right }}{\text { mean }(\text { left }+ \text { right })} \times 100\right|
$$

The count density ratio was calculated as below:

$$
\text { Count Density Ratio }=\text { Caudate } / \text { Putamen }
$$

Seventy-eight patients included in our study had baseline gray matter volume recorded in MRI imaging given on the website. The value of gray matter volume was extracted from high resolution T1-weighted 3T MRI imaging. The gray matter volume was also included for imaging analysis.

\subsection{Statistical analysis}

R (v.4.0.1) was used for statistical analysis. All continuous data that followed the normal distribution examined by Shapiro-Wilks test were presented as the mean(the standard deviation). Continuous data that were not normally distributed were presented as median[quartile]. Student's t-test, Kruskal Willis test, chi square and 
fisher exact test were used to compare baseline features between patients with and without FoG. $P$ value $<0.05$ was presented with '*', $<0.01$ was presented with '**', $<0.001$ was presented with '***'. Multivariate logistic regressions were conducted for factors that had $P$ value $<0.05$ in the initial univariate testing. Odds ratio (OR) and $95 \%$ confidence interval $(\mathrm{CI})$ were reported for both the bivariate and the multivariate analyses. Indexes with $P$ value $<0.05$ in univariate analysis were put in the initial logistic regression model. The initial logistic regression model was built based on backward stepwise selection with the threshold of $P$ value set as 0.05 . The outcome variable was presence or absence of FoG within five years of follow up. A receiver operating characteristic (ROC) curve was created to assess sensitivity and specificity of the predictive model. The Hosmer and Lemeshow goodness-of-fit test was used to assess the model calibration.

\section{Results}

\section{Baseline characteristics}

Overall, 70 (33.0\%) out of 212 PD patients had developed FoG symptoms within five years. Significant difference was observed in the age $\left(P=0.037^{*}\right)$, age at symptom onset $\left(P=0.019^{*}\right)$ and age at PD diagnosis $\left(P=0.031^{*}\right)$ between patients that developed FoG withing five years (pre-FoG patients) and patients without FoG symptoms (non-FoG patients). No significant difference in genetic characteristics as well as CSF biomarkers was observed at the baseline (Table 1). Imaging analysis showed that both left and right, ipsilateral and contralateral caudate, putamen and the striatum had significantly decreased DAT uptake in pre-FoG patients compared with Non-FoG patients. The median time of the pre-FoG patients developing FoG was 2.61 years since diagnosis.

In the motor and non-motor assessments of non-FoG and pre-FoG patients (Table 2), significant differences were observed in motor behavior such as TD/PIGD classification $\left(P=0.009^{* *}\right)$, MDS-UPDRS Part II/III Scores, bradykinesia (Table 1, $\left.P=0.047^{*}\right)$ as well as non-motor examinations such as $\operatorname{SDMT} \operatorname{Score}\left(P<0.001^{* * *}\right)$, 
medRxiv preprint doi: https://doi.org/10.1101/2021.03.11.21253192; this version posted March 12, 2021. The copyright holder for this preprint (which was not certified by peer review) is the author/funder, who has granted medRxiv a license to display the preprint in It is made available under a CC-BY-ND 4.0 International license.

Epworth Sleepiness Scale Score $\left(P=0.005^{* *}\right)$, HVLT Immediate/Total Recall $(P=$ $\left.0.003^{* *}\right)$, SCOPA-AUT Gastrointestinal Score $\left(P=0.006^{* *}\right)$, SCOPA-AUT Urinary Score $\left(P=0.024^{* *}\right)$, SCOPA-AUT Cardiovascular Score $\left(P=0.048^{*}\right)$, and MOCA Score $\left(P=0.039^{*}\right)$. At the visit year five, apart from all the differences showed at baseline, more distinctions were exhibited in Categorical Hoehn \& Yahr $(P=$ $0.002 * *)$, Modified Schwab \& England ADL Score $(P<0.001 * * *)$, depressed mood $\left(P=0.011^{*}\right)$, apathy $\left(P=0.044^{*}\right)$, Benton Judgement of Line Orientation Score $(P=$ $\left.0.006^{* *}\right)$, Geriatric Depression Scale Score $\left(P=0.001^{* *}\right)$, HVLT Discrimination Recognition $\left(P=0.001^{* *}\right)$, Letter Number Sequencing Score $\left(P=0.006^{* *}\right)$, SCOPA-AUT Thermoregulatory Score $\left(P=0.023^{*}\right)$, SCOPA-AUT Total Score $(P<$ $\left.0.001^{* * *}\right)$, Semantic Fluency Total Score $\left(P=0.005^{* *}\right)$ and STAI Total Score $(P=$ $\left.0.015^{*}\right)$.

\section{Motor assessments}

MDS-UPDRS part II score $(\mathrm{OR}=1.13,95 \% \mathrm{CI}=1.05-1.22)$, MDS-UPDRS part III score $(\mathrm{OR}=1.05,95 \% \mathrm{CI}=1.01-1.09), \mathrm{TD} / \mathrm{PIGD}$ classification $(\mathrm{OR}=2.67,95 \% \mathrm{CI}$ $=1.41-5.09)$ and bradykinesia $(\mathrm{OR}=2.74,95 \% \mathrm{CI}=1.15-7.62)$ were found to be correlated with FoG occurrence. Post hoc analyses revealed that non-FoG patients had a significantly higher TD/PIGD ratio compared with pre-FoG group $\left(P=0.009^{* *}\right)$. Freezers had significantly higher MDS-UPDRS part III score $\left(P=0.011^{*}\right)$ compared with non-freezers, indicating worse motor examinations exhibited at baseline. No predictive power of other initial symptoms including resting tremor, rigidity and postural instability was observed between groups (Table 3).

\section{Non-Motor assessments}

Several test scores were found to be related with FoG occurrence. Cognitive tests including SDMT $(\mathrm{OR}=0.95,95 \% \mathrm{CI}=0.91-0.98), \mathrm{HVLT}$ immediate/Total recall $(\mathrm{OR}=0.91,95 \% \mathrm{CI}=0.86-0.97), \mathrm{MOCA}(\mathrm{OR}=0.87,95 \% \mathrm{CI}=0.76-0.99), \mathrm{MCI}$ test score $(\mathrm{OR}=2.49,95 \% \mathrm{CI}=1.12-5.57)$ were found to have significant predicting power (Table 4). 
medRxiv preprint doi: $h t t p s: / / d o i . o r g / 10.1101 / 2021.03 .11 .21253192 ;$ this version posted March 12, 2021. The copyright holder for this preprint (which was not certified by peer review) is the author/funder, who has granted medRxiv a license to display the preprint in

It is made available under a CC-BY-ND 4.0 International license.

Non-cognitive tests that were associated included sleep disturbance: Epworth Sleepiness Scale $(\mathrm{OR}=1.13,95 \% \mathrm{CI}=1.03-1.24)$, $\operatorname{mood}$ disorder $:$ MDS-UPDRS Part I Fatigue $(\mathrm{OR}=1.98,95 \% \mathrm{CI}=1.32-3.06)$ and autonomic dysfunction: SCOPA-AUT gastrointestinal score $(\mathrm{OR}=1.27,95 \% \mathrm{CI}=1.09-1.49)$, SCOPA-AUT urinary score $(\mathrm{OR}=1.18,95 \% \mathrm{CI}=1.06-1.32)$, SCOPA-AUT cardiovascular score $(\mathrm{OR}=1.46,95 \% \mathrm{CI}=1.03-2.16)$ as well as SCOPA-AUT total score $(\mathrm{OR}=1.07$, 95\% CI = 1.02-1.12). In general, cognitive impairment, sleep disturbance, autonomic dysfunction and fatigue were predictive of FoG occurrence (Table 4).

While MDS-UPDRS scores were strong predictors of FoG onset, we further tested whether the changes of the scores were associated with FoG. After screening out of the patients with no MDS-UPDRS scores recorded in year one, 177 patients with 120 patients $(67.8 \%)$ that had FoG symptoms within five years were included. Our results showed that the increase of MDS-UPDRS part II score $(\mathrm{OR}=1.15,95 \% \mathrm{CI}=$ 1.05-1.26, $\left.P=0.003^{* *}\right)$ and MDS-UPDRS total score $(\mathrm{OR}=1.03,95 \% \mathrm{CI}=$ 1.00-1.07, $P=0.030^{*}$ ) from baseline to year-one were risk factors of FoG. However, changes in MDS-UPDRS part I score $(P=0.133)$ and MDS-UPDRS part III score $(P$ $=0.337$ ) were not associated with FoG onset in the study.

\section{DAT uptake and MRI analysis}

Reduction of DAT uptake in the striatum, more specifically, in the caudate striatum $\left(\mathrm{OR}=0.43,95 \% \mathrm{CI}=0.23-0.76, P=0.004^{* *}\right)$ was a strong predictive factor for FoG occurrence. However, the asymmetry index of striatum showed no predictive power in our analysis. In patient sets with gray matter volume extracted from T1-weighted 3T MRI imaging, the value did not present as an independent predictive factor (Table 5).

None of the CSF biomarkers including amyloid- $\beta$ 1-42, total Tau, phosphorylated Tau, total alpha-synuclein as well as genetic features including MAPT, the APOE4 allele, SNCA_rs3910105 and SNCA_rs356181 showed any predictive power in the 
medRxiv preprint doi: https://doi.org/10.1101/2021.03.11.21253192; this version posted March 12, 2021. The copyright holder for this preprint (which was not certified by peer review) is the author/funder, who has granted medRxiv a license to display the preprint in It is made available under a CC-BY-ND 4.0 International license.

univariate analysis. Factors that showed predictive value in univariate analysis were depicted in Figure 1.

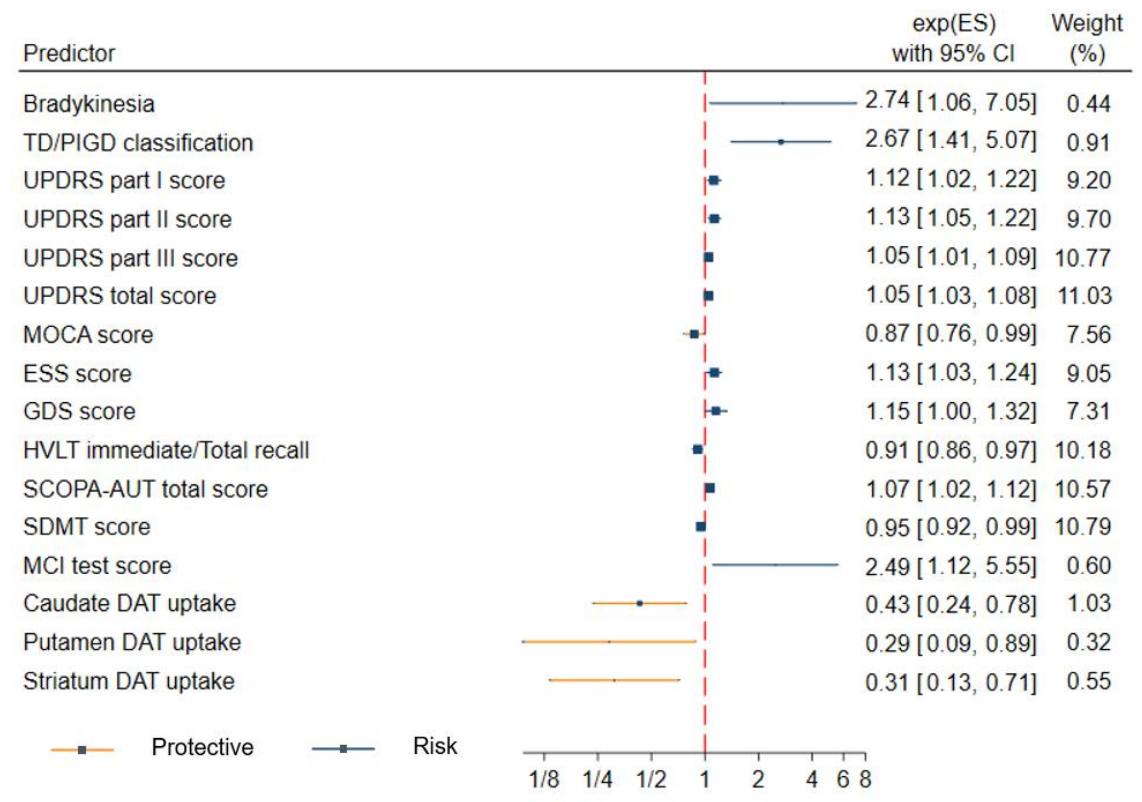

Figure 1 Predictors of the onset of FoG within 5 years follow up. Higher DAT uptake in striatum including caudate and putamen, better cognitive functions such as higher MOCA score, higher HVLT immediate/Total recall value and higher SDMT score (in red) are considered protective factors. Risk factors (in blue) include worse cognitive functions represented as higher MCI test score, worse autonomic functions, depression, sleep disturbance, PIGD subtype and bradykinesia.

\section{Predictive model of FoG}

Three factors including TD/PIGD classification (OR $=2.87, P=0.002 * *)$, MDS-UPDRS total score $\left(\mathrm{OR}=1.04, P=0.007^{* *}\right)$, and SDMT score $(\mathrm{OR}=0.95, P$ $=0.008^{* *}$ ) were selected from all the indicators with $P$ value $<0.05$ at baseline in the multivariate analysis of the logistic regression. MDS-UPDRS total score was the sum of MDS-UPDRS Parts I, II, III, which included both motor examinations and non-motor tests. All the factors showed strong association with FoG occurrence in PD patients. PD patients with the PIGD subtype, higher MDS-UPDRS total score and lower SDMT score were at a higher risk of developing FoG (Table 6). The area under curve (AUC) in the ROC analysis was 0.73 (Figure 2). The $P$ value of the Hosmer and Lemeshow goodness-of-fit test was 0.598 , indicating good calibrations. 
medRxiv preprint doi: https://doi.org/10.1101/2021.03.11.21253192; this version posted March 12, 2021. The copyright holder for this preprint (which was not certified by peer review) is the author/funder, who has granted medRxiv a license to display the preprint in It is made available under a CC-BY-ND 4.0 International license.

The following equation represents the probability $(p)$ of developing FOG in the five following years was presented as below:

$$
\log \left(\frac{p}{1-p}\right)=1.232-1.053 \cdot \mathrm{TD} \_ \text {PIGD }+0.048 \cdot \mathrm{SDMT}-0.037 \cdot \mathrm{UPDRS} \text { total }
$$

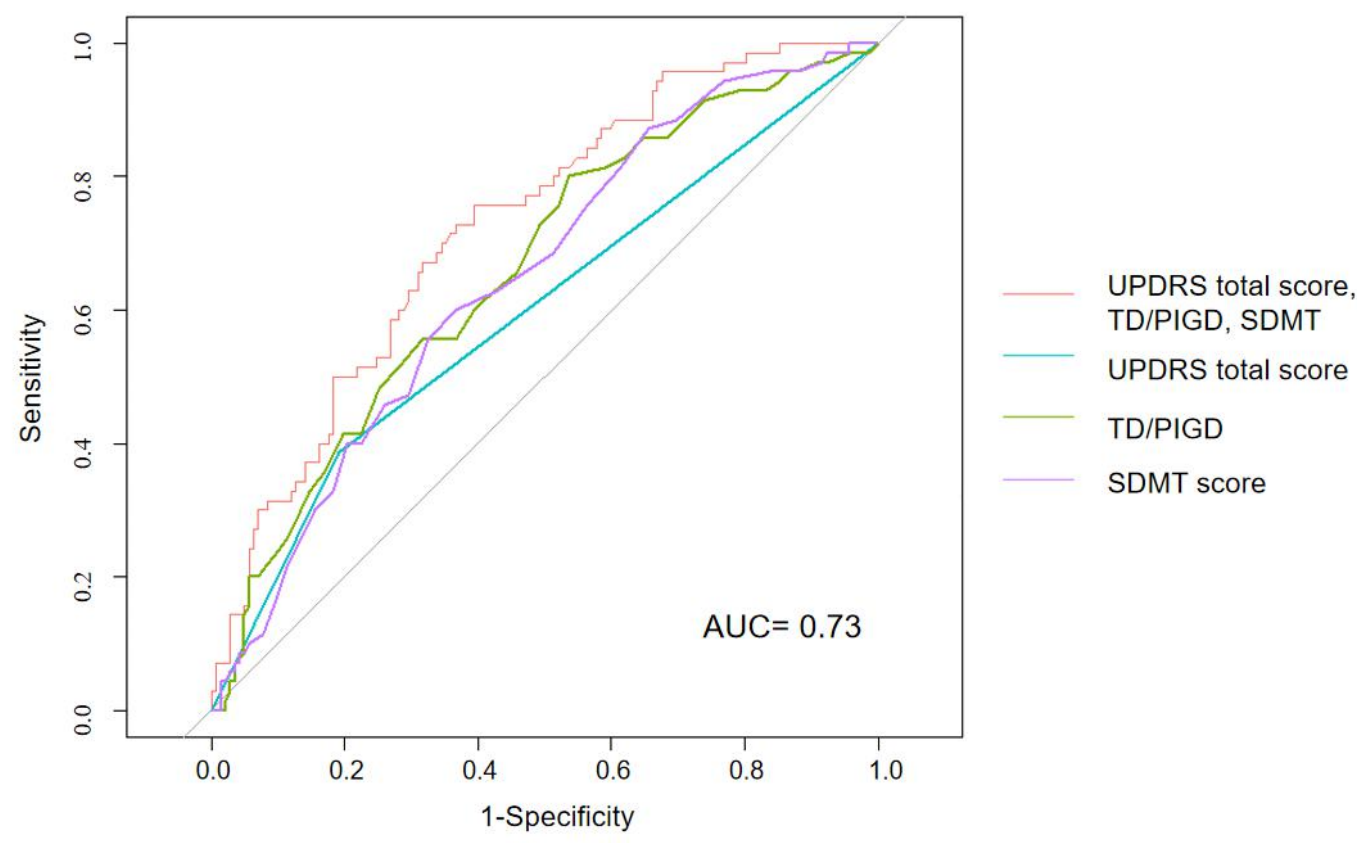

Figure 2 ROC curve analysis for the onset of FoG within 5 years follow up. The AUC for the multivariate predictive model (UPDRS total score, TD/PIGD and SDMT score) is 0.73. 


\section{Discussion}

FoG had a significant negative impact on the health-related quality of life in PD patients ${ }^{19}$. Finding risk factors for FoG patients could help prevent potential outcomes and understand FoG mechanisms in the PD patients. Conflicting results regarding modifiable and non-modifiable risk factors for FoG occurrence were shown in the research before ${ }^{6}$. Our study tried to integrate various aspects of risk factors, using data from de novo PD patients in PPMI cohorts, to predict FoG onset in the early stage of PD. Excluding PD patients with FoG symptoms at baseline, we included 70 patients with FoG occurrence in the follow up duration of five years, and 142 patients with no FoG onset reported. Differences of motor and non-motor examinations were shown at baseline and visit year five. The predictive power of multiple baseline characteristics from clinical symptoms (e.g., bradykinesia, PIGD subtype, fatigue), to imaging parameters (e.g., reduced striatal DAT update) was shown in our study. Multiple logistic regression demonstrated the importance of TD/PIGD classification, MDS-UPDRS total score, and SDMT score in the progression to FoG in PD patients.

First of all, our study confirmed that motor, non-motor risk factors such as PIGD subtype $\left(P=0.003^{* *}\right)$, bradykinesia $\left(P=0.034^{*}\right)$, cognitive impairment, sleep disturbance, autonomic disorders and fatigue $\left(P=0.001^{* *}\right)$ were associated with FoG occurrence. In line with other studies, PD patients with cognitive impairment represented as MCI $\left(P=0.024^{*}\right)$, lower MOCA score $\left(P=0.030^{*}\right)$, lower SDMT score $\left(P=0.001^{* *}\right)$, lower HVLT immediate/Total recall $\left(P=0.004^{* *}\right)$ were prone to develop FoG episodes later on ${ }^{8,18}$. Frontal-executive deficits, characterized by the slowed processing speed, attention and working memory as well as non-cued facilitated recall in prefrontal cortex (PFC), especially the dorsal-lateral part, were predominantly involved in the neuropsychology ${ }^{20}$. While the dopamine-mediated dysfunction of the associative circuit of the basal ganglia which disconnect the dorsal caudate and the PFC was contributory, the limbic and cortical spread of Lewy pathology, the $\beta$-amyloid and tau deposition and the presence of genes such as presence SNCA, APOE4, and MAPT H1 haplotype were all proposed to be 
contributory to the cognitive decline ${ }^{21}$. However, despite the significant cognitive impairment displayed in pre-FoG patients at baseline and visit year five, our studies showed no significant difference in the genetic features and CSF biomarkers between pre-FoG and non-FoG patients. This suggested that these factors contributed to the cognitive impairment in PD patients, especially pre-FoG patients only mildly.

Freezers had significantly sleep disturbances compared with the non-freezers ${ }^{22}$. Consistent with other studies, our study showed that sleep disorder represented as a higher Epworth Sleepiness Scale score $(P=0.012 *)$ was predictive of FoG occurrence $^{16,22}$. The pedunculopontine nucleus (PPN), a target for deep brain stimulation (DBS) for the treatment of parkinsonian gait disorders, may be involved in the association, as the same cells of large cholinergic neurons in PPN were involved in both arousal and motor control, confirmed in vitro, in vivo, and across species $^{22}$. DBS in this region caused sleepiness or rapid transition into sleep, besides improving motor abilities in the FoG patients, further proving the association of sleep disorder with FoG around this region ${ }^{23}$.

Gastrointestinal and urinary autonomic symptoms often predate PD diagnosis by several years ${ }^{24}$. In our study, the impaired gastrointestinal and urinary functions were also associated with FoG occurrence as disease proceeded. This was also confirmed in other studies ${ }^{9,11}$. One hypothesis suggested that PD initiated in the autonomic nerve endings in the gastro-intestinal mucosa, which then spread through the vagal nerve from the gastrointestinal tract to the central nervous system ${ }^{25}$. The idea was supported by the common finding of phosphorylated $\alpha$-synuclein inclusions initiated in hyperbranched, non-myelinated neuron terminals ${ }^{26}$. However, there were few studies that investigated the mechanism of the connections between the autonomic dysfunctions and FoG development. Only one study, assessing the heart rate changes in PD patients during FoG, provided links between impaired motor blockades and autonomic nervous system ${ }^{27}$. There were two studies that found no significant difference of autonomic functions between pre-FoG and non-FoG patients ${ }^{28,29}$. The 
sensitivity of the measurements may account for the inconsistency as both studies derived the autonomic symptom sub-score from items of the MDS-UPDRS parts I and II, while our study used a validated and more concrete measure, SCOPA-AUT to assess the autonomic dysfunctions ${ }^{30}$.

Fatigue was a common symptom in the course of PD development, In FoG patients, the symptom became even more prevalent ${ }^{31}$. As was confirmed in both our and other studies $^{12,32}$, fatigue was also proved to be a risk factor for FoG development. Besides, the clinical feature was associated with many other non-motor symptoms, including daytime sleepiness. While dopaminergic neurons were mostly depleted in PD patients $^{6}$, studies suggested that fatigue was most likely to result from disruption of nondopaminergic pathways ${ }^{33}$. Pavese $\mathrm{N}$ et al. found that the serotoninergic dysfunction in basal ganglia and limbic circuits was associated with fatigue, which also supported the observed associations between fatigue and other non-motor symptoms ${ }^{33}$. In relation with FoG, previous studies have found that the concentration of total serotonin had significant negative correlations with gait freezing ${ }^{34}$. Selective serotonin reuptake inhibitors (SSRIs) and serotonin and norepinephrine reuptake inhibitors (SNRIs) can improve FoG symptoms ${ }^{35}$, which further supported the serotoninergic association with FoG. However, the evidence supporting the anti-depressant therapy of FoG was limited. More studies are needed to validate the efficacy and the pathology of FoG with other nondopaminergic systems.

Second, our model demonstrated that the PIGD subtype ( $\mathrm{P}=0.002 * *)$, MDS-UPDRS total score $\left(\mathrm{P}=0.007^{* *}\right)$ and $\mathrm{SDMT}$ score $\left(\mathrm{P}=0.008^{* *}\right)$ were independent risk factors for FoG occurrence. PD patients experiencing freezing during the walks were more likely to be PIGD subtype ${ }^{36}$, suggesting preexisting gait impairment before FoG occurrence. The predisposing gait impairment provided evidence for the threshold model, which believed that the occurrence of FoG might be a joint effect of several gait disorders that accumulated to a threshold of impairment, finally leading to motor breakdown ${ }^{6,37}$. Since our studies excluded patients with freezing symptoms at baseline, there was no need to worry that the PIGD subtype evaluated by the sum of 
medRxiv preprint doi: https://doi.org/10.1101/2021.03.11.21253192; this version posted March 12, 2021. The copyright holder for this preprint (which was not certified by peer review) is the author/funder, who has granted medRxiv a license to display the preprint in It is made available under a CC-BY-ND 4.0 International license.

MDS-UPDRS items may self-include the 'freezing' itself, which was noticed in some other studies ${ }^{38,39}$. MDS-UPDRS total score was a composite score of both motor and non-motor examinations. While it stood out in our analysis, some studies showed that neither scale of MDS-UPDRS-I/II/III or the total score was well targeted to early PD patients ${ }^{40}$. Evaluating the change of scores using minimal but clinically relevant differences $^{41}$, instead of comparing the baseline difference directly, may be a better examination in defining the disease severity and identifying FoG patients. In our study, we briefly evaluated the increase in MDS-UPDRS-I and MDS-UPDRS total scores after one year from baseline evaluation and confirmed the association, suggesting the feasibility of the methods. SDMT is a commonly used instrument to measure information processing speed, which is required in many cognitive operations ${ }^{42}$. It is sensitive to multiple neurological disorders, including multiple sclerosis, stroke and $\mathrm{PD}^{42}$. While SDMT task performance was a mixed result of visual and motor confounding factors in addition to cognition, a recent study using gaze analysis technique showed that the impaired performance of PD-MCI patients in the written SDMT task were not, even in part, due to visuomotor impairments, further emphasizing the role of cognitive functions played in PD patients in the test. However, since current studies are more concentrated on the relations of SDMT with multiple sclerosis, the physiologic and clinical relations of SDMT performance with FoG remains to be investigated ${ }^{43,44}$.

In line with other studies, our results showed that the more severe loss of striatal dopaminergic binding, shown in early stage of PD patients, could help predict FoG occurrence. While presynaptic striatal dopaminergic denervation was identified as a risk factor before ${ }^{10}$, our study further elucidated that the denervation appears in both left and right, contralateral and ipsilateral striatum, especially in the caudate nucleus. Despite the heterogeneity of neuronal mechanisms in FoG development, anti-coupling between cognitive cortical regions and the caudate nucleus was an independent factor of symptom severity, representing common neural underpinnings of freezing ${ }^{45}$. While evidence suggested the role of hemispheric laterality played in the development of 
medRxiv preprint doi: https://doi.org/10.1101/2021.03.11.21253192; this version posted March 12, 2021. The copyright holder for this preprint (which was not certified by peer review) is the author/funder, who has granted medRxiv a license to display the preprint in It is made available under a CC-BY-ND 4.0 International license .

freezing, no difference in the side of striatum degeneration, indicated by the count density ratio in our analysis was observed in our study ${ }^{46}$.

There were also some negative results shown in our studies. While we had taken genetic characteristics in consideration, our study failed to disclose any predictive power in the items selected. The APOE $\varepsilon 4$ allele was previously reported to be a genetic risk factor for $\mathrm{FoG}$ in $\mathrm{PD}^{47}$. This association seemed to be mediated by A $\beta$-dependent pathways, which itself can independently contribute to the onset of $\mathrm{FoG}^{47}$. However, there was controversy regarding the predictive value of the APOE $\varepsilon 4$ allele, as another study conducted by Factor et al. showed that the APOE $\varepsilon 4$ allele was not associated with FoG in PD patients, and even decreased the risk of postural instability with falling ${ }^{48}$. While SNCA and MAPT genes have been consistently associated with the risk of developing $\mathrm{PD}^{49}$, these genes tend to relate more with the non-motor functions ${ }^{50}$. Potential confounders such as protective genes (CYP2D6*4, LRRK2 and different freezing phenotype may interfere with our analysis ${ }^{36,48,51}$. In our study, gray matter volume was not considered a risk factor for FoG occurrence within five years. There were also studies showing no significant difference between FoG+ and FoG- patients in terms of structural gray matter changes ${ }^{52,53}$. More investigations in the specific pattern of gray matter (GM) tissue were recommended to help identify the difference ${ }^{54}$.

Our studies also have several limitations. First, it is a retrospective study with 212 patients included in a follow-up range of five years. Limited number and of patients included as well as a relatively short period of time may not fully reveal the impact of risk factors in PD patients. Second, while numerous studies have evaluated FoG presence based on self-reported questionnaire, the method can easily mix FoG with other symptoms such as off-state akinesia, given the similar locomotive features. Use of quantitative objective FoG assessments or FoG diagnosis confirmed from wearable sensors may improve the accuracy. Third, selection bias should be noticed as we fully depended on data from PPMI and screened out the patients with no complete data. Other factors influencing the enrollment of subjects or the loss of information in these 
patients may be neglected in our study. More scrutinized selection of the patients and the matching of patient groups based on different symptoms can further elucidate the risk factors in FoG patients.

In summary, our findings determined the risk factors of FoG occurrence among a battery of clinical, imaging as well as genetic characteristics. Our results emphasized the importance of several factors in predicting FoG onset, including PIGD subtype, high MDS-UPDRS total score as risk factors and high SDMT score as a protective factor. Combining these results with further studies in randomized clinical trials and physiological research will help find early therapeutic targets to prevent or postpone FoG onset.

\section{Acknowledgements}

This work was supported by Shanghai Pujiang Program (KH, 19PJ1407500), Medical and Engineering Cross Research Fund from Shanghai Jiao Tong University (KH, YG2019QNA31), Shanghai Municipal Health Commission Clinical Study Special Fund (KH, 20194Y0067), Ruijin Hospital Guangci Excellence Youth Training Program (K.H, GCQN-2019-B10); Ruijin Youth NSFC Cultivation Fund (K.H, 2019QNPY01031). PPMI is sponsored and partially funded by The Michael J. Fox Foundation for Parkinson's Research (MJFF).

\section{Author contributions}

Kejia $\mathrm{Hu}$ designed and conceptualized the study. Fengting Wang collected the data, Fengting Wang and Kejia $\mathrm{Hu}$ analyzed and interpreted the data. Fengting Wang and Kejia $\mathrm{Hu}$ wrote the manuscript. Fengting Wang, Yixin Pan, Weiqiu Jin, Miao Zhang and Kejia $\mathrm{Hu}$ provided critical revisions that were important for the intellectual content. All authors read and approved the final version of the manuscript.

\section{Competing interests}

The authors declare no competing interests. 
medRxiv preprint doi: https://doi.org/10.1101/2021.03.11.21253192; this version posted March 12, 2021. The copyright holder for this preprint (which was not certified by peer review) is the author/funder, who has granted medRxiv a license to display the preprint in

It is made available under a CC-BY-ND 4.0 International license.

\section{Reference}

1. Gilat M, Ligia Silva de Lima A, Bloem BR, Shine JM, Nonnekes J, Lewis SJG. Freezing of gait: Promising avenues for future treatment. Parkinsonism Relat Disord. 2018;52:7-16.

2. Perez-Lloret S, Negre-Pages L, Damier P, et al. Prevalence, determinants, and effect on quality of life of freezing of gait in Parkinson disease. JAMA Neurol. 2014;71(7):884-890.

3. Giladi N, Treves TA, Simon ES, et al. Freezing of gait in patients with advanced Parkinson's disease. J Neural Transm (Vienna). 2001;108(1):53-61.

4. Cucca A, Biagioni MC, Fleisher JE, et al. Freezing of gait in Parkinson's disease: from pathophysiology to emerging therapies. Neurodegener Dis Manag. 2016;6(5):431-446.

5. Jankovic J. Gait disorders. Neurol Clin. 2015;33(1):249-268.

6. Gao C, Liu J, Tan Y, Chen S. Freezing of gait in Parkinson's disease: pathophysiology, risk factors and treatments. Trans/ Neurodegener. 2020;9:12.

7. Giladi N, McDermott MP, Fahn S, et al. Freezing of gait in PD: prospective assessment in the DATATOP cohort. Neurology. 2001;56(12):1712-1721.

8. Forsaa EB, Larsen JP, Wentzel-Larsen T, Alves G. A 12-year population-based study of freezing of gait in Parkinson's disease. Parkinsonism Relat Disord. 2015;21(3):254-258.

9. Kim R, Lee J, Kim HJ, et al. CSF $\beta$-amyloid(42) and risk of freezing of gait in early Parkinson disease. Neurology. 2019;92(1):e40-e47.

10. Kim R, Lee J, Kim Y, et al. Presynaptic striatal dopaminergic depletion predicts the later development of freezing of gait in de novo Parkinson's disease: An analysis of the PPMI cohort. Parkinsonism Relat Disord. 2018;51:49-54.

11. Herman T, Shema-Shiratzky S, Arie L, Giladi N, Hausdorff JM. Depressive symptoms may increase the risk of the future development of freezing of gait in patients with Parkinson's disease: Findings from a 5-year prospective study. Parkinsonism Relat Disord. 2019;60:98-104.

12. Zhang $H$, Yin $X$, Ouyang Z, et al. A prospective study of freezing of gait with early Parkinson disease in Chinese patients. Medicine (Baltimore). 2016;95(26):e4056.

13. Chung SJ, Lee YH, Yoo HS, et al. White matter hyperintensities as a predictor of freezing of gait in Parkinson's disease. Parkinsonism Relat Disord. 2019;66:105-109.

14. da Silva CP, de MAG, Cabello Acero PH, et al. Clinical profiles associated with LRRK2 and GBA mutations in Brazilians with Parkinson's disease. J Neurol Sci. 2017;381:160-164.

15. Ehgoetz Martens KA, Lukasik EL, Georgiades MJ, et al. Predicting the onset of freezing of gait: A longitudinal study. Mov Disord. 2018;33(1):128-135.

16. Banks SJ, Bayram E, Shan G, LaBelle DR, Bluett B. Non-motor predictors of freezing of gait in Parkinson's disease. Gait Posture. 2019;68:311-316.

17. Pardoel S, Kofman J, Nantel J, Lemaire ED. Wearable-Sensor-based Detection and Prediction of Freezing of Gait in Parkinson's Disease: A Review. Sensors (Basel). 2019;19(23).

18. Schrag A, Siddiqui UF, Anastasiou Z, Weintraub D, Schott JM. Clinical variables and biomarkers in prediction of cognitive impairment in patients with newly diagnosed Parkinson's disease: a cohort study. Lancet Neurol. 2017;16(1):66-75.

19. Walton CC, Shine JM, Hall JM, et al. The major impact of freezing of gait on quality of life in Parkinson's disease. J Neurol. 2015;262(1):108-115.

20. Aarsland D, Creese B, Politis M, et al. Cognitive decline in Parkinson disease. Nat Rev Neurol. 
medRxiv preprint doi: https://doi.org/10.1101/2021.03.11.21253192; this version posted March 12, 2021. The copyright holder for this preprint (which was not certified by peer review) is the author/funder, who has granted medRxiv a license to display the preprint in It is made available under a CC-BY-ND 4.0 International license.

2017;13(4):217-231.

21. Biundo R, Weis L, Antonini A. Cognitive decline in Parkinson's disease: the complex picture. NPJ Parkinsons Dis. 2016;2:16018.

22. Tang X, Yu L, Yang J, et al. Association of sleep disturbance and freezing of gait in Parkinson disease: prevention/delay implications. J Clin Sleep Med. 2020.

23. Arnulf I, Ferraye M, Fraix V, et al. Sleep induced by stimulation in the human pedunculopontine nucleus area. Ann Neurol. 2010;67(4):546-549.

24. Borghammer P, Knudsen K, Fedorova TD, Brooks DJ. Imaging Parkinson's disease below the neck. NPJ Parkinsons Dis. 2017;3:15.

25. Hawkes CH, Del Tredici K, Braak H. Parkinson's disease: a dual-hit hypothesis. Neuropathol Appl Neurobiol. 2007;33(6):599-614.

26. Orimo S, Uchihara T, Nakamura A, et al. Axonal alpha-synuclein aggregates herald centripetal degeneration of cardiac sympathetic nerve in Parkinson's disease. Brain. 2008;131(Pt 3):642-650.

27. Maidan I, Plotnik M, Mirelman A, Weiss A, Giladi N, Hausdorff JM. Heart rate changes during freezing of gait in patients with Parkinson's disease. Mov Disord. 2010;25(14):2346-2354.

28. Hall JM, Shine JM, O'Callaghan C, et al. Freezing of Gait and its Associations in the Early and Advanced Clinical Motor Stages of Parkinson's Disease: A Cross-Sectional Study. J Parkinsons Dis. 2015;5(4):881-891.

29. Hall JM, Shine JM, Walton CC, et al. Early phenotypic differences between Parkinson's disease patients with and without freezing of gait. Parkinsonism Relat Disord. 2014;20(6):604-607.

30. Rodriguez-Blazquez C, Forjaz MJ, Frades-Payo B, de Pedro-Cuesta J, Martinez-Martin P. Independent validation of the scales for outcomes in Parkinson's disease-autonomic (SCOPA-AUT). Eur J Neurol. 2010;17(2):194-201.

31. Prasad S, Lenka A, Stezin A, et al. A Comparative Study of Early and Late Onset Freezing of Gait in Parkinson's Disease. Ann Indian Acad Neurol. 2018;21(4):256-262.

32. Sawada M, Wada-Isoe K, Hanajima R, Nakashima K. Clinical features of freezing of gait in Parkinson's disease patients. Brain Behav. 2019;9(4):e01244.

33. Pavese N, Metta V, Bose SK, Chaudhuri KR, Brooks DJ. Fatigue in Parkinson's disease is linked to striatal and limbic serotonergic dysfunction. Brain. 2010;133(11):3434-3443.

34. Tohgi H, Abe T, Takahashi S, Takahashi J, Hamato H. Concentrations of serotonin and its related substances in the cerebrospinal fluid of parkinsonian patients and their relations to the severity of symptoms. Neurosci Lett. 1993;150(1):71-74.

35. Takahashi M, Tabu H, Ozaki A, Hamano T, Takeshima T. Antidepressants for Depression, Apathy, and Gait Instability in Parkinson's Disease: A Multicenter Randomized Study. Intern Med. 2019;58(3):361-368.

36. Lord SR, Bindels H, Ketheeswaran M, et al. Freezing of Gait in People with Parkinson's Disease: Nature, Occurrence, and Risk Factors. J Parkinsons Dis. 2020;10(2):631-640.

37. Plotnik M, Giladi N, Hausdorff JM. Is freezing of gait in Parkinson's disease a result of multiple gait impairments? Implications for treatment. Parkinsons Dis. 2012;2012:459321.

38. Lichter DG, Benedict RHB, Hershey LA. Freezing of Gait in Parkinson's Disease: Risk Factors, Their Interactions, and Associated Nonmotor Symptoms. Parkinsons Dis. 2021;2021:8857204.

39. Lichter DG, Benedict RHB, Hershey LA. Importance of Balance-Gait Disorder as a Risk Factor for Cognitive Impairment, Dementia and Related Non-Motor Symptoms in Parkinson's 
medRxiv preprint doi: https://doi.org/10.1101/2021.03.11.21253192; this version posted March 12, 2021. The copyright holder for this preprint (which was not certified by peer review) is the author/funder, who has granted medRxiv a license to display the preprint in It is made available under a CC-BY-ND 4.0 International license .

Disease. J Parkinsons Dis. 2018;8(4):539-552.

40. Regnault A, Boroojerdi B, Meunier J, Bani M, Morel T, Cano S. Does the MDS-UPDRS provide the precision to assess progression in early Parkinson's disease? Learnings from the Parkinson's progression marker initiative cohort. J Neurol. 2019;266(8):1927-1936.

41. Makkos A, Kovács M, Aschermann Z, et al. Are the MDS-UPDRS-Based Composite Scores Clinically Applicable? Mov Disord. 2018;33(5):835-839.

42. Strober L, DeLuca J, Benedict RH, et al. Symbol Digit Modalities Test: A valid clinical trial endpoint for measuring cognition in multiple sclerosis. Mult Scler. 2019;25(13):1781-1790.

43. Chen MH, Chiaravalloti ND, Genova HM, Costa SL. Visual and motor confounds on the symbol digit modalities test. Mult Scler Relat Disord. 2020;45:102436.

44. Pascoe M, Alamri Y, Dalrymple-Alford J, Anderson T, MacAskill M. The Symbol-Digit Modalities Test in Mild Cognitive Impairment: Evidence from Parkinson's Disease Patients. Eur Neurol. 2018;79(3-4):206-210.

45. Ehgoetz Martens KA, Hall JM, Georgiades MJ, et al. The functional network signature of heterogeneity in freezing of gait. Brain. 2018;141(4):1145-1160.

46. Pieruccini-Faria F, Ehgoetz Martens KA, Silveira CR, Jones JA, Almeida QJ. Side of basal ganglia degeneration influences freezing of gait in Parkinson's disease. Behav Neurosci. 2015;129(2):214-218.

47. Kim R, Shin JH, Park S, Kim HJ, Jeon B. Apolipoprotein E $\varepsilon 4$ genotype and risk of freezing of gait in Parkinson's disease. Parkinsonism Relat Disord. 2020;81:173-178.

48. Factor SA, Steenland NK, Higgins DS, et al. Postural instability/gait disturbance in Parkinson's disease has distinct subtypes: an exploratory analysis. I Neurol Neurosurg Psychiatry. 2011;82(5):564-568.

49. Elbaz A, Ross OA, loannidis JP, et al. Independent and joint effects of the MAPT and SNCA genes in Parkinson disease. Ann Neurol. 2011;69(5):778-792.

50. Huertas I, Jesús S, García-Gómez FJ, et al. Genetic factors influencing frontostriatal dysfunction and the development of dementia in Parkinson's disease. PLoS One. 2017;12(4):e0175560.

51. O'Hara DM, Pawar G, Kalia SK, Kalia LV. LRRK2 and $\alpha$-Synuclein: Distinct or Synergistic Players in Parkinson's Disease? Front Neurosci. 2020;14:577.

52. Li E, Ruan X, Li Y, Zhang G, Li M, Wei X. Exploring Cortical Thickness Alteration in Parkinson Disease Patients with Freezing of Gaits. Neural Plast. 2020;2020:8874119.

53. Canu E, Agosta F, Sarasso E, et al. Brain structural and functional connectivity in Parkinson's disease with freezing of gait. Hum Brain Mapp. 2015;36(12):5064-5078.

54. Kostic VS, Agosta F, Pievani M, et al. Pattern of brain tissue loss associated with freezing of gait in Parkinson disease. Neurology. 2012;78(6):409-416. 
medRxiv preprint doi: https://doi.org/10.1101/2021.03.11.21253192; this version posted March 12, 2021. The copyright holder for this preprint (which was not certified by peer review) is the author/funder, who has granted medRxiv a license to display the preprint in It is made available under a CC-BY-ND 4.0 International license.

Table 1 Demographic, disease, imaging and genetic characteristics of pre-FoG and non-FoG subjects with Parkinson's disease at baseline.

\begin{tabular}{|c|c|c|c|}
\hline & Non-FoG $(n=142)$ & Pre-FoG $(n=70)$ & $P$ \\
\hline \multicolumn{4}{|l|}{ Demographic information } \\
\hline Age (years) & $60.8[53.2 ; 68.1]$ & $64.6[57.0 ; 69.4]$ & $0.037 *$ \\
\hline Age at symptom onset & $59.3[51.5 ; 66.2]$ & $62.4[55.5 ; 67.5]$ & $0.019^{*}$ \\
\hline Age at $\mathrm{PD}$ diagnosis & $60.4[53.0 ; 67.2]$ & $64.4[56.6 ; 68.6]$ & $0.031^{*}$ \\
\hline Gender, female & $48(33.8 \%)$ & $20(28.6 \%)$ & 0.541 \\
\hline Years of education & $16.0[14.0 ; 18.0]$ & $16.0[14.0 ; 18.0]$ & 0.221 \\
\hline Family members with PD (any) & $37(26.1 \%)$ & $18(25.7 \%)$ & 1.000 \\
\hline Duration of disease since diagnosis (months) & $4.13[2.57 ; 7.27]$ & $4.92[2.33 ; 7.17]$ & 0.988 \\
\hline \multicolumn{4}{|l|}{ Disease characteristics } \\
\hline Side most affected at PD onset & & & 0.294 \\
\hline Left & $56(39.4 \%)$ & $34(48.6 \%)$ & \\
\hline Right & $85(59.9 \%)$ & $35(50.0 \%)$ & \\
\hline Symmetric & $1(0.70 \%)$ & $1(1.43 \%)$ & \\
\hline Resting tremor & $115(81.0 \%)$ & $52(74.3 \%)$ & 0.345 \\
\hline Rigidity & $106(74.6 \%)$ & $57(81.4 \%)$ & 0.353 \\
\hline Bradykinesia & $113(79.6 \%)$ & $64(91.4 \%)$ & $0.047^{*}$ \\
\hline Postural instability & $6(4.2 \%)$ & $8(11.4 \%)$ & 0.074 \\
\hline \multicolumn{4}{|l|}{ SPECT-DAT } \\
\hline Mean caudate DAT uptake & $2.14(0.51)$ & $1.92(0.53)$ & $0.004 * *$ \\
\hline Mean putamen DAT uptake & $0.84[0.70 ; 1.00]$ & $0.75[0.60 ; 0.87]$ & $0.015^{*}$ \\
\hline Mean striatum DAT uptake & $1.49[1.27 ; 1.69]$ & $1.33[1.14 ; 1.55]$ & $0.006^{* *}$ \\
\hline Right caudate & $2.15(0.57)$ & $1.91(0.56)$ & $0.003 * *$ \\
\hline Left caudate & $2.13(0.54)$ & $1.94(0.60)$ & $0.021^{*}$ \\
\hline Right putamen & $0.86[0.65 ; 1.08]$ & $0.70[0.58 ; 0.95]$ & $0.012^{*}$ \\
\hline Left putamen & $0.80[0.59 ; 1.03]$ & $0.71[0.55 ; 0.96]$ & 0.162 \\
\hline Right striatum & $2.92[2.48 ; 3.58]$ & $2.66[2.18 ; 3.04]$ & $0.004 * *$ \\
\hline Left striatum & $2.99(0.83)$ & $2.70(0.88)$ & $0.023^{*}$ \\
\hline Caudate Asymmetry Index & $15.7[9.37 ; 25.8]$ & $17.2[9.40 ; 28.2]$ & 0.304 \\
\hline Putamen Asymmetry Index & $33.0[16.3 ; 54.9]$ & $34.3[18.1 ; 47.9]$ & 0.778 \\
\hline Striatum Asymmetry Index & $21.2[10.8 ; 32.8]$ & $22.0[14.0 ; 32.1]$ & 0.452 \\
\hline Left count density ratio & $2.61[2.23 ; 3.23]$ & $2.60[2.20 ; 2.93]$ & 0.816 \\
\hline Right count density ratio & $2.50[2.00 ; 2.91]$ & $2.51[2.05 ; 2.98]$ & 0.793 \\
\hline Contralateral striatum & $2.61[2.22 ; 3.07]$ & $2.40[2.08 ; 2.84]$ & $0.013 *$ \\
\hline Contralateral caudate & $1.93[1.63 ; 2.25]$ & $1.73[1.49 ; 2.03]$ & $0.008^{* *}$ \\
\hline Contralateral putamen & $0.68[0.55 ; 0.86]$ & $0.64[0.52 ; 0.78]$ & 0.179 \\
\hline Contralateral count density ratio & $2.77[2.38 ; 3.33]$ & $2.68[2.42 ; 3.08]$ & 0.386 \\
\hline Ipsilateral striatum & $3.30[2.74 ; 3.84]$ & $2.91[2.51 ; 3.40]$ & $0.006^{* *}$ \\
\hline Ipsilateral caudate & $2.31(0.53)$ & $2.09(0.60)$ & $0.011^{*}$ \\
\hline
\end{tabular}


medRxiv preprint doi: https://doi.org/10.1101/2021.03.11.21253192; this version posted March 12, 2021. The copyright holder for this preprint (which was not certified by peer review) is the author/funder, who has granted medRxiv a license to display the preprint in It is made available under a CC-BY-ND 4.0 International license.

$\begin{array}{llll}\text { Ipsilateral putamen } & 0.97[0.78 ; 1.21] & 0.84[0.66 ; 1.09] & 0.008^{* *} \\ \begin{array}{l}\text { Ipsilateral count density ratio } \\ \text { MRI }\end{array} & 2.33[1.91 ; 2.71] & 2.35[1.97 ; 2.82] & 0.585 \\ \text { Gray matter volume in } & & & \\ \text { T1-weighted 3T MRI\# } & 818202.7(58076.1) & 802946.3(62169.4) & 0.313 \\ \text { CSF biomarkers } & & & \\ \text { Abeta } & 899[694 ; 1286] & 931[715 ; 1123] & 0.655 \\ \text { Tau } & 161[129 ; 208] & 161[144 ; 202] & 0.546 \\ \text { pTau } & 13.3[11.0 ; 17.1] & 13.9[11.5 ; 17.2] & 0.497 \\ \text { aSyn } & 1452[1112 ; 1853](n=141) & 1446[1154 ; 1737] & 0.841\end{array}$

Genetic characteristics

\begin{tabular}{|c|c|c|c|}
\hline APOE & & & 0.936 \\
\hline $\mathrm{e} 2 / \mathrm{e} 2$ & $2(1.41 \%)$ & $0(0.00 \%)$ & \\
\hline $\mathrm{e} 2 / \mathrm{e} 4$ & $3(2.11 \%)$ & $2(2.86 \%)$ & \\
\hline $\mathrm{e} 3 / \mathrm{e} 2$ & $16(11.3 \%)$ & $9(12.9 \%)$ & \\
\hline $\mathrm{e} 3 / \mathrm{e} 3$ & $91(64.1 \%)$ & $42(60.0 \%)$ & \\
\hline $\mathrm{e} 4 / \mathrm{e} 3$ & $27(19.0 \%)$ & $16(22.9 \%)$ & \\
\hline $\mathrm{e} 4 / \mathrm{e} 4$ & $3(2.11 \%)$ & $1(1.43 \%)$ & \\
\hline SNCA_rs356181 & & & 0.207 \\
\hline $\mathrm{C} / \mathrm{C}$ & $46(32.4 \%)$ & $20(28.6 \%)$ & \\
\hline $\mathrm{C} / \mathrm{T}$ & $62(43.7 \%)$ & $39(55.7 \%)$ & \\
\hline $\mathrm{T} / \mathrm{T}$ & $34(23.9 \%)$ & $11(15.7 \%)$ & \\
\hline SNCA_rs3910105 & & & 0.483 \\
\hline $\mathrm{C} / \mathrm{C}$ & $24(16.9 \%)$ & $8(11.4 \%)$ & \\
\hline $\mathrm{C} / \mathrm{T}$ & $72(50.7 \%)$ & $35(50.0 \%)$ & \\
\hline $\mathrm{T} / \mathrm{T}$ & $46(32.4 \%)$ & $27(38.6 \%)$ & \\
\hline APOE_e4 & & & 0.795 \\
\hline 0 & $109(76.8 \%)$ & $51(72.9 \%)$ & \\
\hline 1 & $30(21.1 \%)$ & $18(25.7 \%)$ & \\
\hline 2 & $3(2.11 \%)$ & $1(1.43 \%)$ & \\
\hline MAPT & & & 0.677 \\
\hline $\mathrm{H} 1 / \mathrm{H} 1$ & $92(64.8 \%)$ & $43(61.4 \%)$ & \\
\hline $\mathrm{H} 1 / \mathrm{H} 2$ & $44(31.0 \%)$ & $22(31.4 \%)$ & \\
\hline $\mathrm{H} 2 / \mathrm{H} 2$ & $6(4.23 \%)$ & $5(7.14 \%)$ & \\
\hline
\end{tabular}

\#24 pre-FoG patients and 54 non-FoG patients with data of gray matter volume given on the website were included in MRI analysis. Indicators that have missing value had the number of patients recorded in the bracket. Continuous data that followed the normal distribution were presented as the mean(the standard deviation). Continuous data not normally distributed were presented as median[quartile]. 
medRxiv preprint doi: https://doi.org/10.1101/2021.03.11.21253192; this version posted March 12, 2021. The copyright holder for this preprint (which was not certified by peer review) is the author/funder, who has granted medRxiv a license to display the preprint in It is made available under a CC-BY-ND 4.0 International license.

$* P<0.05 .{ }^{*} * P<0.01 .{ }^{* * *} P<0.001$. 
1 Table 2 Motor and non-motor assessments of pre-FoG and non-FoG subjects with Parkinson's disease at baseline and visit year five.

\begin{tabular}{|c|c|c|c|c|c|c|}
\hline \multirow[b]{2}{*}{ Index } & \multicolumn{3}{|c|}{ Baseline } & \multicolumn{3}{|c|}{ Visit Year Five } \\
\hline & $\begin{array}{l}\text { Non-FoG } \\
(n=142)\end{array}$ & $\begin{array}{l}\text { Pre-FoG } \\
(n=70)\end{array}$ & $\boldsymbol{P}$ & $\begin{array}{l}\text { Non-FoG } \\
(n=142)\end{array}$ & $\begin{array}{l}\text { Pre-FoG } \\
(n=70)\end{array}$ & $\boldsymbol{P}$ \\
\hline Categorical Hoehn \& Yahr (OFF) & & & 0.745 & $(n=112)$ & $(n=50)$ & $0.002 * *$ \\
\hline Stage 1 & $72(50.7 \%)$ & $33(47.1 \%)$ & & $12(10.7 \%)$ & $3(6.00 \%)$ & \\
\hline Stage 2 & $69(48.6 \%)$ & $36(51.4 \%)$ & & $99(88.4 \%)$ & $40(80.0 \%)$ & \\
\hline Stages 3-5 & $1(0.70 \%)$ & $1(1.43 \%)$ & & $1(0.89 \%)$ & $7(14.0 \%)$ & \\
\hline Total Rigidity Score (OFF) & $3.00[2.00 ; 5.00]$ & $4.00[2.00 ; 5.00]$ & 0.415 & $\begin{array}{l}6.00[3.00 ; 8.00] \\
(n=112)\end{array}$ & $\begin{array}{l}6.50[4.00 ; 9.00] \\
(n=50)\end{array}$ & 0.369 \\
\hline TD/PIGD classification (OFF) & & & $0.009 * *$ & $(n=112)$ & $(n=50)$ & $0.002 * *$ \\
\hline $\mathrm{TD}$ & $115(81.0 \%)$ & $43(61.4 \%)$ & & $79(71.2 \%)$ & $21(42.0 \%)$ & \\
\hline PIGD & $16(11.3 \%)$ & $17(24.3 \%)$ & & $22(19.8 \%)$ & $19(38.0 \%)$ & \\
\hline Indeterminate & $11(7.75 \%)$ & $10(14.3 \%)$ & & $10(9.01 \%)$ & $10(20.0 \%)$ & \\
\hline Tremor Score (OFF) & $4.00[2.00 ; 6.00]$ & $4.00[2.00 ; 6.00]$ & 0.320 & $\begin{array}{l}6.00[2.00 ; 9.00] \\
(n=112)\end{array}$ & $\begin{array}{l}6.00[2.25 ; 8.75] \\
(n=50)\end{array}$ & 0.709 \\
\hline Modified Schwab \& England ADL Score & $95.0[90.0 ; 100]$ & $90.0[90.0 ; 95.0]$ & 0.056 & $90.0[80.0 ; 90.0]$ & $80.0[70.0 ; 90.0]$ & $<0.001 * * *$ \\
\hline MDS-UPDRS Part I Score & $4.00[2.00 ; 6.00]$ & $5.50[3.25 ; 7.75]$ & $0.015^{*}$ & $7.00[5.00 ; 10.8]$ & $10.0[8.00 ; 14.8]$ & $<0.001 * * *$ \\
\hline MDS-UPDRS Part I Cognitive Impairment & & & 0.529 & & & 0.181 \\
\hline 0 & $112(78.9 \%)$ & $51(72.9 \%)$ & & $92(64.8 \%)$ & $38(54.3 \%)$ & \\
\hline 1 & $28(19.7 \%)$ & $17(24.3 \%)$ & & $40(28.2 \%)$ & $21(30.0 \%)$ & \\
\hline 2 & $2(1.41 \%)$ & $2(2.86 \%)$ & & $8(5.63 \%)$ & $9(12.9 \%)$ & \\
\hline 3 & $0(0.00 \%)$ & $0(0.00 \%)$ & & $2(1.41 \%)$ & $2(2.86 \%)$ & \\
\hline MDS-UPDRS Part I Hallucinations and Psychosis & & & 0.721 & & & 0.373 \\
\hline 0 & $137(96.5 \%)$ & $67(95.7 \%)$ & & $123(86.6 \%)$ & 64 (91.4\%) & \\
\hline
\end{tabular}




\begin{tabular}{|c|c|c|c|c|c|c|}
\hline 1 & $5(3.52 \%)$ & $3(4.29 \%)$ & & $18(12.7 \%)$ & $5(7.14 \%)$ & \\
\hline 2 & $0(0.00 \%)$ & $0(0.00 \%)$ & & $1(0.70 \%)$ & $1(1.43 \%)$ & \\
\hline \multicolumn{2}{|l|}{ MDS-UPDRS Part I Depressed Mood } & & 0.446 & & & $0.011 *$ \\
\hline 0 & $109(76.8 \%)$ & $48(68.6 \%)$ & & $109(76.8 \%)$ & $42(60.0 \%)$ & \\
\hline 1 & $29(20.4 \%)$ & $19(27.1 \%)$ & & $27(19.0 \%)$ & $18(25.7 \%)$ & \\
\hline 2 & $4(2.82 \%)$ & $3(4.29 \%)$ & & $4(2.82 \%)$ & $9(12.9 \%)$ & \\
\hline 3 & $0(0.00 \%)$ & $0(0.00 \%)$ & & $2(1.41 \%)$ & $1(1.43 \%)$ & \\
\hline \multicolumn{2}{|l|}{ MDS-UPDRS Part I Anxious Mood } & & 0.702 & & & 0.077 \\
\hline 0 & $92(64.8 \%)$ & $42(60.0 \%)$ & & $84(59.2 \%)$ & $35(50.0 \%)$ & \\
\hline 1 & $46(32.4 \%)$ & $25(35.7 \%)$ & & $43(30.3 \%)$ & $24(34.3 \%)$ & \\
\hline 2 & $3(2.11 \%)$ & $3(4.29 \%)$ & & $10(7.04 \%)$ & $11(15.7 \%)$ & \\
\hline 3 & $1(0.70 \%)$ & $0(0.00 \%)$ & & $5(3.52 \%)$ & $0(0.00 \%)$ & \\
\hline \multicolumn{2}{|l|}{ MDS-UPDRS Part I Apathy } & & 0.420 & & & $0.044^{*}$ \\
\hline 0 & $123(86.6 \%)$ & $57(81.4 \%)$ & & $109(76.8 \%)$ & $45(64.3 \%)$ & \\
\hline 1 & $18(12.7 \%)$ & $12(17.1 \%)$ & & $23(16.2 \%)$ & $14(20.0 \%)$ & \\
\hline 2 & $1(0.70 \%)$ & $1(1.43 \%)$ & & $6(4.23 \%)$ & $10(14.3 \%)$ & \\
\hline 3 & $0(0.00 \%)$ & $0(0.00 \%)$ & & $4(2.82 \%)$ & $1(1.43 \%)$ & \\
\hline \multicolumn{2}{|c|}{ MDS-UPDRS Part I Features of Dopamine Dysregulation Syndrome } & & 0.600 & & & 0.074 \\
\hline 0 & $140(98.6 \%)$ & $68(97.1 \%)$ & & $133(93.7 \%)$ & $61(87.1 \%)$ & \\
\hline 1 & $2(1.41 \%)$ & $2(2.86 \%)$ & & $5(3.52 \%)$ & $8(11.4 \%)$ & \\
\hline 2 & $0(0.00 \%)$ & $0(0.00 \%)$ & & $4(2.82 \%)$ & $1(1.43 \%)$ & \\
\hline \multicolumn{2}{|l|}{ MDS-UPDRS Part I Fatigue } & & $0.001 * *$ & & & $<0.001 * * *$ \\
\hline 0 & $77(54.2 \%)$ & $30(42.9 \%)$ & & $57(40.1 \%)$ & $21(30.0 \%)$ & \\
\hline 1 & $61(43.0 \%)$ & $27(38.6 \%)$ & & $62(43.7 \%)$ & $19(27.1 \%)$ & \\
\hline 2 & $4(2.82 \%)$ & $8(11.4 \%)$ & & $19(13.4 \%)$ & $25(35.7 \%)$ & \\
\hline
\end{tabular}




\begin{tabular}{|c|c|c|c|c|c|c|}
\hline 3 & $0(0.00 \%)$ & $5(7.14 \%)$ & & $4(2.82 \%)$ & $4(5.71 \%)$ & \\
\hline 4 & $0(0.00 \%)$ & $0(0.00 \%)$ & & $0(0.00 \%)$ & $1(1.43 \%)$ & \\
\hline MDS-UPDRS Part II Score & $4.00[2.00 ; 6.00]$ & $6.00[3.00 ; 9.00]$ & $<0.001 * * *$ & $7.00[4.00 ; 11.0]$ & $13.0[9.00 ; 18.0]$ & $<0.001 * * *$ \\
\hline MDS-UPDRS Part III Score (OFF) & $17.0[13.2 ; 24.0]$ & $21.0[16.2 ; 26.0]$ & $0.008 * *$ & $\begin{array}{l}29.0 \\
{[20.5 ; 35.5]} \\
(n=112)\end{array}$ & $\begin{array}{l}35.0[24.5 ; 42.2] \\
(n=50)\end{array}$ & $0.007 * *$ \\
\hline MDS-UPDRS Total Score (OFF) & $27.0[19.0 ; 34.8]$ & $34.0[27.0 ; 41.8]$ & $<0.001 * * *$ & $\begin{array}{l}43.0[34.0 ; 54.5] \\
(n=111)\end{array}$ & $\begin{array}{l}58.5[43.0 ; 72.8] \\
(n=50)\end{array}$ & $<0.001 * * *$ \\
\hline MCI test score $(=1)$ & $14(9.86 \%)$ & $15(21.4 \%)$ & $0.036^{*}$ & $17(12.0 \%)$ & $\begin{array}{l}18(26.1 \%) \\
(n=69)\end{array}$ & $0.017 *$ \\
\hline MOCA Score (adjusted for education) & $28.0[26.0 ; 29.0]$ & $27.0[25.0 ; 28.8]$ & $0.037^{*}$ & $28.0[26.0 ; 29.0]$ & $27.0[24.2 ; 28.8]$ & $0.012 * *$ \\
\hline UPSIT Score & $24.0[17.0 ; 28.0]$ & $20.0[14.0 ; 29.8]$ & 0.294 & $(n=0)$ & $(n=0)$ & - \\
\hline Benton Judgement of Line Orientation Score & $14.0[12.0 ; 15.0]$ & $14.0[12.0 ; 15.0]$ & 0.965 & $\begin{array}{l}13.0[12.0 ; 14.0] \\
(n=141)\end{array}$ & $\begin{array}{l}12.0[10.0 ; 14.0] \\
(n=69)\end{array}$ & $0.006^{* *}$ \\
\hline Epworth Sleepiness Scale Score & $5.00[3.00 ; 6.00]$ & $6.00[4.00 ; 8.00]$ & $0.005^{* *}$ & $6.00[4.00 ; 10.8]$ & $7.50[5.00 ; 11.0]$ & $0.015^{*}$ \\
\hline REM Sleep Behavior Disorder Questionnaire Score & $3.00[2.00 ; 5.00]$ & $4.00[2.00 ; 5.00]$ & 0.241 & $4.00[2.00 ; 7.00]$ & $4.50[2.00 ; 8.00]$ & 0.444 \\
\hline Geriatric Depression Scale Score & $1.00[0.00 ; 3.00]$ & $2.00[1.00 ; 3.75]$ & 0.071 & $2.00[1.00 ; 3.00]$ & $2.50[1.00 ; 5.00]$ & $0.001 * *$ \\
\hline STAI Total Score & $\begin{array}{l}60.0 \\
{[51.0 ; 74.0]}\end{array}$ & $62.0[50.0 ; 71.8]$ & 0.662 & $57.5[49.0 ; 68.8]$ & $67.0[51.0 ; 82.0]$ & $0.015^{*}$ \\
\hline Any QUIP disorder & $31(21.8 \%)$ & $13(18.6 \%)$ & 0.771 & $28(19.7 \%)$ & $23(32.9 \%)$ & 0.053 \\
\hline SDMT Score & $44.0[37.0 ; 49.0]$ & $39.0[33.0 ; 45.0]$ & $<0.001 * * *$ & $43.0[34.0 ; 50.0]$ & $\begin{array}{l}36.0[29.0 ; 44.0] \\
(n=69)\end{array}$ & $<0.001 * * *$ \\
\hline
\end{tabular}




\begin{tabular}{|c|c|c|c|c|c|c|}
\hline HVLT Immediate/Total Recall & $26.0[22.0 ; 29.0]$ & $24.0[20.2 ; 26.0]$ & $0.003 * *$ & $26.0[22.0 ; 31.0]$ & $\begin{array}{l}22.0[18.0 ; 26.0] \\
(n=69)\end{array}$ & $<0.001 * * *$ \\
\hline HVLT Discrimination Recognition & $10.0[9.00 ; 11.0]$ & $10.0[8.25 ; 11.0]$ & 0.176 & $12.0[10.2 ; 12.0]$ & $\begin{array}{l}11.0[9.00 ; 12.0] \\
(\mathrm{n}=69)\end{array}$ & $0.001 * *$ \\
\hline HVLT Retention & $0.90[0.78 ; 1.00]$ & $0.88[0.70 ; 1.00]$ & 0.176 & $0.92[0.83 ; 1.00]$ & $\begin{array}{l}0.91[0.75 ; 1.00] \\
(\mathrm{n}=69)\end{array}$ & 0.113 \\
\hline SCOPA-AUT Gastrointestinal Score & $\begin{array}{l}1.00[0.00 ; 2.00] \\
(n=141)\end{array}$ & $2.00[1.00 ; 4.00]$ & $0.006^{* *}$ & $2.00[1.00 ; 4.00]$ & $4.00[3.00 ; 5.75]$ & $<0.001 * * *$ \\
\hline SCOPA-AUT Urinary Score & $3.00[2.00 ; 5.00]$ & $4.00[2.25 ; 6.00]$ & $0.024 *$ & $5.00[3.00 ; 6.00]$ & $5.50[3.00 ; 8.00]$ & $0.033^{*}$ \\
\hline SCOPA-AUT Cardiovascular Score & $0.00[0.00 ; 1.00]$ & $0.00[0.00 ; 1.00]$ & $0.048^{*}$ & $0.00[0.00 ; 1.00]$ & $1.00[0.00 ; 1.00]$ & $0.019^{*}$ \\
\hline SCOPA-AUT Thermoregulatory Score & $1.00[0.00 ; 2.00]$ & $0.50[0.00 ; 2.00]$ & 0.591 & $1.00[0.00 ; 2.00]$ & $2.00[0.25 ; 3.00]$ & $0.023^{*}$ \\
\hline SCOPA-AUT Pupillomotor Score & $0.00[0.00 ; 3.00]$ & $0.00[0.00 ; 2.00]$ & 0.465 & $0.00[0.00 ; 3.00]$ & $0.00[0.00 ; 3.00]$ & 0.272 \\
\hline SCOPA-AUT Sexual Dysfunction Score & $0.00[0.00 ; 2.00]$ & $\begin{array}{l}0.00[0.00 ; 2.00] \\
(\mathrm{n}=69)\end{array}$ & 0.791 & $1.00[0.00 ; 2.00]$ & $1.00[0.00 ; 3.00]$ & 0.490 \\
\hline SCOPA-AUT Total Score & $\begin{array}{l}7.00[5.00 ; 11.0] \\
(n=141)\end{array}$ & $\begin{array}{l}8.00[6.00 ; 13.0] \\
(n=69)\end{array}$ & 0.063 & $10.5[7.25 ; 14.0]$ & $14.5[10.0 ; 18.8]$ & $<0.001 * * *$ \\
\hline Semantic Fluency Total Score & $50.0[43.0 ; 58.0]$ & $47.0[42.0 ; 56.0]$ & 0.089 & $51.1(12.6)$ & $\begin{array}{l}45.7(13.0) \\
(n=69)\end{array}$ & $0.005^{* *}$ \\
\hline Letter Number Sequencing Score & $11.0[9.00 ; 12.0]$ & $10.0[9.00 ; 12.0]$ & 0.208 & $10.6(2.95)$ & $\begin{array}{l}9.33(3.11) \\
(n=69)\end{array}$ & $0.006^{* *}$ \\
\hline
\end{tabular}

2 \#Indicators that have missing value had the number of patients recorded in the bracket.

$3 * P<0.05 . * * P<0.01 .{ }^{* * *} P<0.001$. 
medRxiv preprint doi: https://doi.org/10.1101/2021.03.11.21253192; this version posted March 12, 2021. The copyright holder for this preprint (which was not certified by peer review) is the author/funder, who has granted medRxiv a license to display the preprint in It is made available under a CC-BY-ND 4.0 International license.

4 Table 3 Univariate analysis of motor symptoms at baseline for FoG onset within 5 years of follow 5 up.

\begin{tabular}{lcccc}
\hline \multicolumn{1}{c}{ Index } & OR & \multicolumn{2}{c}{$\mathbf{9 5 \%}$ CI } & P \\
\hline Resting tremor & 0.68 & 0.35 & 1.35 & 0.263 \\
Rigidity & 1.49 & 0.75 & 3.12 & 0.273 \\
Bradykinesia & 2.74 & 1.15 & 7.62 & $0.034^{*}$ \\
Postural instability & 2.92 & 0.98 & 9.23 & 0.056 \\
Total rigidity score & 1.03 & 0.92 & 1.15 & 0.607 \\
TD/PIGD classification (TD subtype) & 2.67 & 1.41 & 5.09 & $0.003^{* *}$ \\
Tremor & 0.94 & 0.85 & 1.04 & 0.244 \\
MDS-UPDRS part II score & 1.13 & 1.05 & 1.22 & $0.001^{* *}$ \\
MDS-UPDRS part III score & 1.05 & 1.01 & 1.09 & $0.011^{*}$ \\
MDS-UPDRS total score & 1.05 & 1.02 & 1.07 & $<0.001^{* * *}$ \\
Modified Schwab \& England ADL score & 0.95 & 0.90 & 1.00 & 0.079 \\
\hline
\end{tabular}

${ }^{*} P<0.05 .{ }^{* *} P<0.01 .{ }^{* * *} P<0.001$. 
medRxiv preprint doi: https://doi.org/10.1101/2021.03.11.21253192; this version posted March 12, 2021. The copyright holder for this preprint (which was not certified by peer review) is the author/funder, who has granted medRxiv a license to display the preprint in It is made available under a CC-BY-ND 4.0 International license.

8 Table 4 Univariate analysis of nonmotor symptoms at baseline for FoG onset within 5 years of 9 follow up.

\begin{tabular}{|c|c|c|c|c|}
\hline Index & OR & & $\% \mathbf{C I}$ & $\boldsymbol{P}$ \\
\hline MCI test score $(=1)$ & 2.49 & 1.12 & 5.57 & $0.024 *$ \\
\hline MOCA score & 0.87 & 0.76 & 0.99 & $0.030^{*}$ \\
\hline MDS-UPDRS part I score & 1.12 & 1.03 & 1.23 & $0.007 * *$ \\
\hline MDS-UPDRS Part I Anxious Mood & 1.18 & 0.72 & 1.93 & 0.506 \\
\hline MDS-UPDRS Part I Apathy & 1.44 & 0.70 & 2.92 & 0.304 \\
\hline MDS-UPDRS Part I Cognitive Impairment & 1.38 & 0.76 & 2.47 & 0.284 \\
\hline MDS-UPDRS Part I Features of Dopamine Dysregulation Syndrome & 2.06 & 0.24 & 17.46 & 0.475 \\
\hline MDS-UPDRS Part I Depressed Mood & 1.41 & 0.82 & 2.39 & 0.208 \\
\hline MDS-UPDRS Part I Fatigue & 1.98 & 1.32 & 3.06 & $0.001 * *$ \\
\hline MDS-UPDRS Part I Hallucinations and Psychosis & 1.23 & 0.25 & 5.15 & 0.784 \\
\hline UPSIT score & 0.98 & 0.95 & 1.02 & 0.315 \\
\hline Benton Judgement of Line Orientation score & 0.99 & 0.87 & 1.14 & 0.908 \\
\hline REM sleep behavior disorder questionnaire score & 1.06 & 0.94 & 1.19 & 0.320 \\
\hline Epworth Sleepiness Scale score & 1.13 & 1.03 & 1.24 & $0.012^{*}$ \\
\hline Geriatric Depression Scale score & 1.15 & 1.00 & 1.32 & $0.048^{*}$ \\
\hline STAI total score & 1.00 & 0.99 & 1.02 & 0.560 \\
\hline QUIP score & 0.97 & 0.56 & 1.59 & 0.899 \\
\hline SDMT score & 0.95 & 0.91 & 0.98 & $0.001 * *$ \\
\hline HVLT immediate/Total recall & 0.91 & 0.86 & 0.97 & $0.004 * *$ \\
\hline SCOPA-AUT total score & 1.07 & 1.02 & 1.12 & $0.009 * *$ \\
\hline SCOPA-AUT cardiovascular score & 1.46 & 1.03 & 2.16 & $0.043^{*}$ \\
\hline SCOPA-AUT gastrointestinal score & 1.27 & 1.09 & 1.49 & $0.003 * *$ \\
\hline SCOPA-AUT pupillomotor score & 0.77 & 0.46 & 1.22 & 0.285 \\
\hline SCOPA-AUT sexual dysfunction score & 1.09 & 0.91 & 1.30 & 0.366 \\
\hline SCOPA-AUT thermoregulatory score & 0.95 & 0.76 & 1.18 & 0.661 \\
\hline SCOPA-AUT urinary score & 1.18 & 1.06 & 1.32 & $0.003 * *$ \\
\hline Semantic Fluency total score & 0.97 & 0.95 & 1.00 & 0.055 \\
\hline Letter Number Sequencing score & 0.92 & 0.82 & 1.02 & 0.127 \\
\hline
\end{tabular}

$* P<0.05 .{ }^{* *} P<0.01 . * * * P<0.001$. 
medRxiv preprint doi: https://doi.org/10.1101/2021.03.11.21253192; this version posted March 12, 2021. The copyright holder for this preprint (which was not certified by peer review) is the author/funder, who has granted medRxiv a license to display the preprint in It is made available under a CC-BY-ND 4.0 International license.

12 Table 5 Univariate analysis of imaging data at baseline for FoG onset within 5 years of follow up.

\begin{tabular}{|c|c|c|c|c|}
\hline Index & OR & \multicolumn{2}{|c|}{$95 \%$ CI } & $\boldsymbol{P}$ \\
\hline Mean caudate DAT uptake & 0.43 & 0.23 & 0.76 & $0.004 * *$ \\
\hline Mean putamen DAT uptake & 0.29 & 0.09 & 0.84 & $0.030^{*}$ \\
\hline Mean striatum DAT uptake & 0.31 & 0.13 & 0.69 & $0.006^{* *}$ \\
\hline Caudate Asymmetry Index & 1.02 & 0.99 & 1.04 & 0.173 \\
\hline Putamen Asymmetry Index & 1.00 & 0.99 & 1.01 & 0.815 \\
\hline Striatum Asymmetry Index & 1.01 & 0.99 & 1.03 & 0.331 \\
\hline Left caudate & 0.53 & 0.3 & 0.89 & $0.019^{*}$ \\
\hline Left putamen & 0.44 & 0.17 & 1.05 & 0.075 \\
\hline Left striatum & 0.66 & 0.45 & 0.93 & $0.021^{*}$ \\
\hline Left count density ratio & 0.97 & 0.66 & 1.43 & 0.894 \\
\hline Right caudate & 0.45 & 0.26 & 0.76 & $0.004 * *$ \\
\hline Right putamen & 0.44 & 0.17 & 1.02 & 0.068 \\
\hline Right striatum & 0.61 & 0.42 & 0.87 & $0.008^{*}$ \\
\hline Right count density ratio & 1.02 & 0.67 & 1.53 & 0.930 \\
\hline Contralateral caudate & 0.43 & 0.23 & 0.75 & $0.005 * *$ \\
\hline Contralateral putamen & 0.34 & 0.09 & 1.10 & 0.086 \\
\hline Contralateral striatum & 0.55 & 0.35 & 0.84 & $0.008 * *$ \\
\hline Contralateral count density ratio & 0.82 & 0.54 & 1.21 & 0.329 \\
\hline Ipsilateral caudate & 0.48 & 0.28 & 0.82 & $0.009 * *$ \\
\hline Ipsilateral putamen & 0.40 & 0.17 & 0.88 & $0.030^{*}$ \\
\hline Ipsilateral striatum & 0.62 & 0.43 & 0.88 & $0.009 * *$ \\
\hline Ipsilateral count density ratio & 1.20 & 0.77 & 1.86 & 0.411 \\
\hline \multicolumn{5}{|l|}{ MRI } \\
\hline \multicolumn{5}{|l|}{ Gray matter volume in } \\
\hline T1-weighted 3T MRI\# & 1.00 & 1.00 & 1.00 & 0.295 \\
\hline
\end{tabular}

MRI analysis.

${ }^{*} P<0.05 .{ }^{* *} P<0.01 .{ }^{* * *} P<0.001$. 
medRxiv preprint doi: https://doi.org/10.1101/2021.03.11.21253192; this version posted March 12, 2021. The copyright holder for this preprint (which was not certified by peer review) is the author/funder, who has granted medRxiv a license to display the preprint in It is made available under a CC-BY-ND 4.0 International license .

17 Table 6 Multivariate analysis at baseline for the onset of FoG within 5 years of follow up.

\begin{tabular}{|c|c|c|c|c|}
\hline Index & OR & \multicolumn{2}{|c|}{$95 \%$ CI } & $\boldsymbol{P}$ \\
\hline TD/PIGD classification & 2.87 & 1.45 & 5.72 & $0.002 * *$ \\
\hline MDS-UPDRS total score & 1.04 & 1.01 & 1.07 & $0.007 * *$ \\
\hline SDMT score & 0.95 & 0.92 & 0.99 & $0.008^{* *}$ \\
\hline
\end{tabular}

$18 * P<0.05 . * * P<0.01 . * * * P<0.001$.

19 